\title{
Monetary Approach to Nigerian Balance of Payments
}

\author{
INIMINO, Edet Etim ${ }^{l}$, AKPAN, James Essien ${ }^{2}$, OTUBU, Osaretin Paul ${ }^{3}$ and ALEX, Iriabije O. ${ }^{4}$ \\ ${ }^{1 \& 4}$ Department of Economics, University of Uyo, Nigeria, ${ }^{2}$ Department of Economics and Management Science, \\ Nigerian Police Academy Kano, Nigeria, ${ }^{3}$ Department of Economics, University of Port Harcourt, Nigeria.
}

\begin{abstract}
The study examined monetary approach to Nigerian balance of payments. Therefore, the broad objective of the study was to examine the impact of monetary policy on balance of payments in Nigeria from 1970 to 2015. The econometrics methods of Co-integration and Error Correction Mechanism were employed as the analytical techniques. The Co-integration result revealed the existence of a long-run relationship among the variables. The result of the parsimonious ECM revealed that exchange rate and credit to private sector have significant impact on balance of payments in Nigeria. While money supply and interest rate do not have significant impact on balance of payments in Nigeria. Moreover, the coefficient of ECM was rightly signed (that is negative) and statistically significant at conventional level. This means that, the short run dynamics adjust to long run equilibrium relationship. Based on these findings, the study recommended that monetary authority should make the financial sector to be viable in order to provide credit at lower interest rates and adopt a managed floating exchange rate policy to redress the problem of exchange rate variation in order to raise the BOPs position of Nigeria.
\end{abstract}

Key Words: Monetary Policy, BOPs, Money Supply, Co-integration and ECM.

\section{INTRODUCTION}

Monetary policy is a deliberate action of the government designed to affect the quantity and cost of money supply. This action is usually taken by the central bank which is the highest monetary authority of a country. According to Anyanwu and Oaikhenan (1995), monetary policy involves measures designed to control the volume, cost, availability and direction of money and credit in an economy to achieve some specified macroeconomic policy objectives. That is, a conscious effort by the monetary authorities to regulate the money supply and credit conditions for the purpose of achieving certain broad economic objectives among which is balance of payments equilibrium. Similarly, Gbosi (2005) submitted that monetary policy aims at controlling money supply in order to check unwanted trends in an economy. These unwanted trends in the economy may include disequilibrium in the balance of payments.

Meanwhile, Umo (2012) defined BOPs statement as an annual summary of a country's trade and finance accounts showing receipts from, and payments to, the outside world. A typical balance of payments statement consists of the current account, capital account and monetary transactions account (Gbosi, 2011). Balance of payments disequilibrium is one macro-economic problem facing modern nations including Nigeria. Thus, achieving balance of payments equilibrium is considered one of the major goals of monetary policy. However, the Nigeria's external sector has been experiencing continual instability on her general BOPs and this has called for anxiety and query on the likely causes of this instability. For example, in 2013, the external sector was under pressure with an estimated overall balance of payments (BOPs) deficit equivalent to 0.2 per cent of gross domestic product (GDP). The development reflected, mainly, the decline in external reserves, rising external debt and increased repatriation of investment income by foreign investors (CBN, 2013). 
In 2014, the overall balance of payments (BOPs) account recorded a deficit equivalent of 1.7 per cent of GDP, which reflected the drawdown of external reserves. The decline in current account was induced largely by lower export receipts, from 15,262.8 billion in 2013 to 12,988.3 billion in 2014 and higher import bills, from 8,628.7 billion in 2013 to 9,686.8 billion (CBN, 2014). Once more, the crash in the international prices of crude oil in 2015 and the subsequent low inflow of foreign exchange into the economy, impacted adversely on the external account. Consequently, the external sector also recorded an overall balance of payments deficit of $1,150.13$ billion, equivalent to 1.4 per cent of gross domestic product (GDP) in 2015 (CBN, 2015).

To tackle the problem of balance of payments disequilibrium, the Nigerian government had adopted various economic policies over the years. For instance, the introduction of Structural Adjustment Programme (SAP) by the Babangida Administration in 1986 is a case in point. The major objective of SAP was to restructure and diversify the productive base of the economy. The country's monetary authority (CBN) was advised to devalue the naira in order to discourage imports and promote exports. Unfortunately, since 1986, the Nigerian external sector had been characterized by persistent deficits in the balance of payments (Gbosi, 2015). However, it is the responsibility of the Central Bank of Nigeria to design and implement monetary policy to ensure that the country is not in deficit in its external transactions.

Therefore, over the years, the Central Bank of Nigeria has formulated and implemented monetary policy actions in order to significantly reduce the shortfalls of the Nigeria's BOPs. Put differently, Monetary authorities in Nigeria have enunciated and implemented a myriad of monetary policy actions in an attempt to solve the problem of BOPs in Nigeria. Monetary policy instruments adopted include monetary policy rate (MPR), open market operations (OMO), reserve requirements (RR), cash and liquidity ratio, the exchange rate and moral suasion. Yet, the Nigeria's BOPs trouble has remained worse because of the pitiable non-oil export performance, persistent decline in the country's foreign exchange, high import, preference for foreign goods and services over domestic goods and services, stagnated agriculture, pressure of inflation, inefficiency of the manufacturing sector and falling oil prices in the foreign oil market. Strictly speaking, despite all the laudable efforts of monetary authorities at addressing the problem of BOPs deficits, balance of payments deficits still remains one of the major problems in Nigeria. Supporting this, Gbosi (2001) submitted that in recent years, there have been continuous shortfalls in the country's BOPs.

Nevertheless, a number of studies have been carried out on different aspects of this subject using various measures to examine the association between monetary policy variables and BOPs. However, the studies have provided mixed results. While studies such as Imoughele \& Ismaila (2015), Unaimikogbo \& Enoma (2011), and Adamu \& Itsede (2010) showed that monetary policy variables have a significant impact on balance of payments. Ajayi (2014) discovered a negative association between monetary variables and BOPs. Danjuma (2013), Boateng \& Ayentim (2013) and Fleermuys (2005) found that in Nigeria, BOPs is not a purely monetary phenomenon. The above state of affairs raised pertinent questions: what is the relationship between balance of payments (BOPs) and money supply in Nigeria? What is the relationship between balance of payments and exchange rate in Nigeria? What is the relationship between balance of payments and interest rate in Nigeria? What is the relationship between balance of payments and credit to private sectors in Nigeria? Answers to these questions were the major concern of this work. Therefore, the main objective of this study was to ascertain the impact of monetary policy on balance of payments in Nigeria from 1970-2015. Specifically, the study: (a) examined the relationship between money supply and BOPs in Nigeria (b) investigated the relationship between exchange rate and BOPs in Nigeria (c) examined the relationship between interest rate and BOPs in Nigeria (d) ascertained the relationship between credit to private sector and BOPs in Nigeria. The paper is separated into five sections, namely introduction, literature review, materials and methods, results and discussion; and conclusion and recommendations. 


\section{LITERATURE REVIEW}

\section{Conceptual Framework}

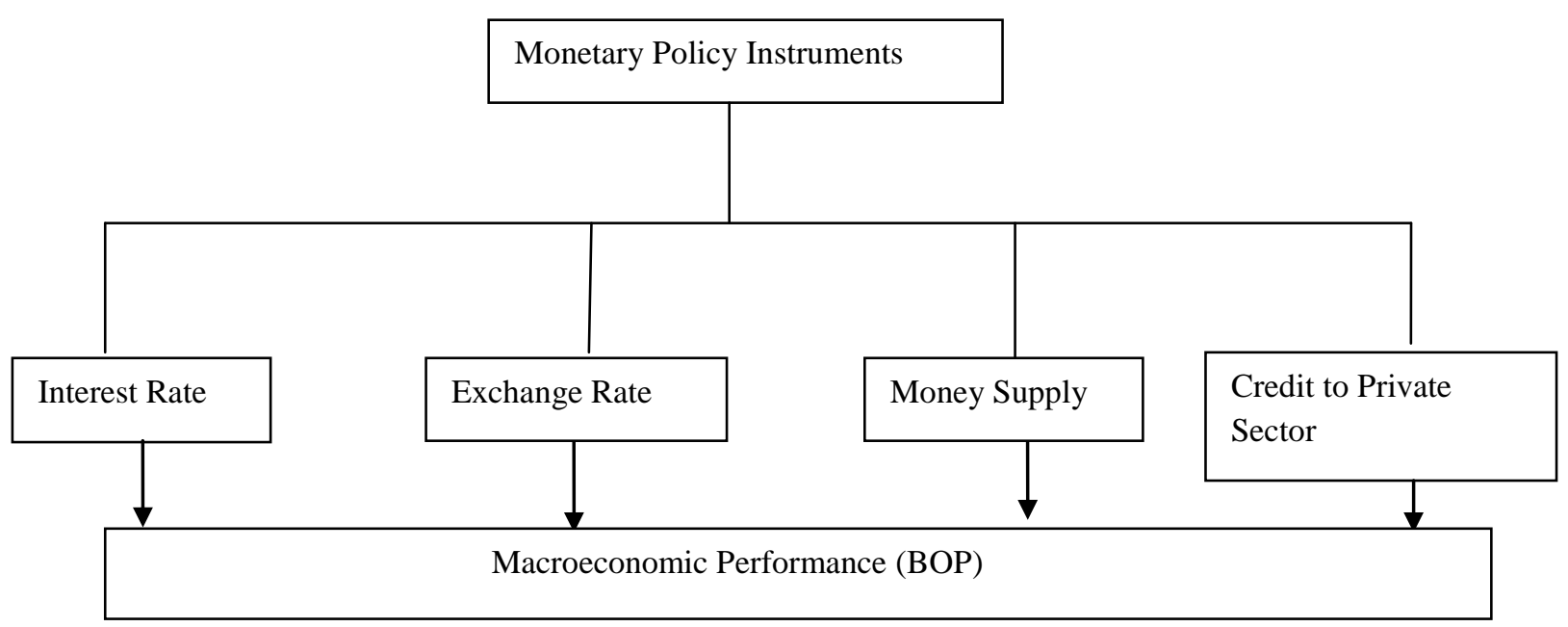

Figure 2.1: As conceptualized by the authors

By monetary policy instruments, we mean various weapons which are used by the Central Bank to regulate the behaviour of banks and other financial institutions. For instance, interest rate (monetary policy rate) changes affect the amount of money in the country through their effects on the demand for loans. Since the rate of interest is the price of a loan, any change in it will affect the demand for loans. An increase in interest rate will reduce the demand for loans because it has made them more expensive. The outcome of this will be a decrease in the amount of money in the country. A decrease in interest rate will increase the demand for loans because it has made them cheaper than before. In this case, the result will be an increase in the amount of money in the country.

In addition, the Central Bank acting on behalf of the government may cause changes in interest rates in the system in order to achieve monetary objectives including balance of payments equilibrium. It may do this directly by simply fixing some interest rate, or indirectly by changing the rate of interest at which it lends to banks and the other financial institutions which borrow from it. An increase in the rate of interest charged by the Central Bank (sometime called the 'rediscount rate') will obviously push up the rates of interest in the system. A decrease will have the opposite effect (Akpakpan, 1994).

Furthermore, real money supply is positively related to BOPs, an increase in money supply leads to a fall in interest rate. A fall in interest rate will lead to a reduction in the cost of borrowing leading to an increase in investment thereby causing an increase in aggregate demand and an increase in real domestic output. It will also lead to a decrease in real effective exchange rate. The decrease in real effective exchange rate is followed by increase in net export, real domestic output and favourable balance of payments. Real domestic credit is positively related to balance of payments. An increase in domestic credit will lead to an increase real money supply which will in turn raise the BOPs position.

Balance of payments (BOPs) is an accounting statement that summarizes the economic transactions between residents of the home country and all other countries. BOPs statement has three main parts, namely the current account section, capital account section and the financing or monetary movements account. The current account summarizes information about purchases and sales of goods and services across national boundaries. Capital account records changes in the country's assets in foreign countries, and changes in foreign countries' assets in our country. While financing account shows how the government settled a deficit (when in deficit) and what it did with the surplus (when in surplus). Often, a surplus is used to increase external reserves, while a deficit is met by running 
down external reserves. Whenever a country's payments exceed her receipts from foreign transactions, such country's BOPs becomes unfavourable (disequilibrium). According to Akpakpan (1999), the approach towards solving balance of payments disequilibrium (problem) depends on its cause. Where a balance of payments problem is caused by high levels of investment abroad (i.e., by capital account transactions or where the country has made high levels of investment abroad and/or granted a high level of aid to other countries), it may not be a bad thing after all if the earnings on the investment are returned to the country. Such earnings would improve the country's balance on investment income in the current account section. When it is caused by deficits on the current account, then there is a real problem which the country will have to try to solve if it wishes to avoid excessive external borrowing with all its economic and political problems.

If the problem is caused by a deficit on the current account, which shows that the country has imported more goods and services than it has exported, the country will have to strive to increase its exports and reduce its imports. The specific measures which could help a country in pursuing this objective include the following:

i. A stimulation of local production (with improvements in the quality of output) in order to reduce the need to import goods from other countries.

ii. A stimulation of export production in particular in order to increase the earnings from exports. To be successful in this, those engaged in production will have to strive to produce high quality products, and to do so efficiently.

iii. Exchange control, i.e., controlling access to foreign currencies.

iv. Import restrictions through tariffs and quotas.

v. A devaluation of the country's currency. However, devaluation is usually adopted as a last resort (Akpakpan, 1999).

\section{Theoretical Literature}

Attempts to explain the causes of balance of payments problem are sometime referred to as approaches to balance of payments. This study was based on monetary approach to balance of payments. Monetary approach to BOPs originates from the David Hume price-specie-flow mechanism, which was launched as a counter-argument to the faith of mercantilist that a country can achieve a relentless BOPs surplus by import-substituting and exportpromoting policies (Bobai, 2013). According to Robinson (2003), the monetary approach seems to be the best in explaining the problem of the BOPs. It views the balance of payments as purely monetary phenomena. It explains a country's balance of payments in terms of demand for and supply of money. Specifically, this approach postulates that the causes of BOPs disequilibrium can be traced to the disequilibrium in the monetary market. The monetarists postulate some positions for the BOP. First, that if the demand for money is not equal to the supply of money i.e. $\mathbf{M}^{\mathrm{d}}$ $\neq \mathrm{M}^{\mathrm{s}}$, then the BOPs will certainly be in disequilibrium. Second, that if $\mathrm{M}^{\mathrm{s}}>\mathrm{M}^{\mathrm{d}}$, that is money supply is greater than money demand, there will be excess money holding in the hands of the public which will increase their purchasing power and eventually result to an inflationary condition. Such inflation condition will make local products more expensive, thus increasing the demand for foreign products, high financial transfer and eventual BOPs shortfall. It will also make local products less competitive in the foreign market. Under such circumstance tight or contractionary monetary policy is more appropriate to correct the disequilibrium in the BOPs. The third condition demands that, $\mathrm{M}^{\mathrm{d}}>\mathrm{M}^{\mathrm{s}}$, When this condition holds, it means that there is less money in the hands of the public. The effect will be falling domestic prices which will make local products more competitive in the foreign market. This will cause inflow of foreign exchange and eventual increase in foreign reserves and as such BOPs surplus. The last condition is where $\mathbf{M}^{\mathrm{s}}=\mathbf{M}^{\mathrm{d}}$, this is equilibrium condition. At this condition the BOPs is at equilibrium. The MABP, therefore, largely emphasizes the monetary implications of BOPs disequilibria. Monetary approach to balance of payments looks upon overall level of price as what determines of the genuine worth of nominal assets, money and external debt. Relative prices seem to play a secondary role as they are considered to have only a transitory effect on the BOPs (Umer, Muhammad, Abro, Sheikh, \& Ghazali, 2010). The official model for monetary approach to 
balance of payments comprises money demand and supply functions plus an equilibrium state. The replica contains subsequent equations:

$M^{s}=(R+D)$

$M^{\mathrm{d}}=\mathrm{f}(\mathrm{Y}, \mathrm{P}, \mathrm{I})$

$\mathrm{M}^{\mathrm{s}}=\mathrm{M}^{\mathrm{d}}$.

Where $=\mathrm{M}^{\mathrm{s}}=$ Money supply, $\mathrm{M}^{\mathrm{d}}=$ Money demand, $\mathrm{R}=$ International Reserve, $\mathrm{D}=$ Domestic credit, $\mathrm{Y}=$ Level of real domestic income, $\mathrm{P}=$ Price level and $\mathrm{I}=$ Rate of interest.

The monetary theory states that there is a positive association between money demand and income $\left(\partial \mathbf{M}^{\mathrm{d}} / \partial \mathrm{Y}>0\right)$, and between money demand and the price level $\left(\partial \mathrm{M}^{\mathrm{d}} / \partial \mathrm{P}>0\right)$. However, there is a negative association between money demand and the interest rate $\left(\partial \mathrm{M}^{\mathrm{d}} / \partial \mathrm{I}<0\right)$. If interest rates are increased, people will demand less money as the opportunity cost of holding cash balances is increased, thus creating incentives for investing in interest-yielding securities.

Then the reserve flow equation is written as: $\Delta R=\Delta[F(Y, P, I)]-\Delta D \ldots \ldots \ldots \ldots \ldots(4)$. Where equations; one to three are combined, placing the variables in percentage changes and isolating reserves as the dependent variable. Equation four is the basic MABP equation. It reveals that foreign reserves (BOPs) represent the variation in growth of money demand from the growth of domestic credit with the monetary consequences of the BOPs bringing the money market into equilibrium. The foreign reserves equalize the changes in domestic credit and the coefficient of $\Delta \mathrm{D}$ is recognized as an offset coefficient. It reveals the extent to which changes in domestic credit are offset by changes in international reserves, and the coefficient assumes a negative sign for MAPB in the reserve flow equation (Dhliwayo, 1996).

However, the monetary approach to balance of payment has been criticized for concentrating on the change in international reserves in order to determine a country's external position (Lanciaux, 1990). According to Bobai (2013) the approach's characteristic of excluding other important factors - such as the current account balance, trade deficit/surplus, and the extent of a country's international borrowing - is regarded as being short-sighted with respect to the real factors which determine a country's balance of payments. In response to this it is argued that devaluation, tariffs and import quotas can only have an effect on the balance of payments by influencing the stock of money. The monetary approach to balance of payments was explicitly also expected to include the government budget constraint in its identity; however, as Howard and Mamingi (2002) pointed out, there exist relations linking fiscal policy and the creation of credit, so that limitation of budget is not in reality removed. Alawode (1997) also criticize it for being a 'long-run' model. Policies need to be made on a short-term basis; therefore a model that only works in the long run should not be regarded as particularly useful.

In addition, the monetary approach to balance of payments has been criticized for its assumption of a stable demand for money (i.e., the demand for money is stable in the long run but not in short in the short run), which might not always hold for some countries, as money demand can shift from a state of stability due to changes in a country's financial environment. Critics including Alawode (1997) and Bobai (2013) argued that "the demand for money in small open economies is also subjected to external shocks in foreign trade. Currency substitution (holding foreign currency instead of domestic currency) is another factor influencing the trade balance; hence, the demand for money. Contend, therefore, that the greater the degree of substitution between the domestic and foreign currencies, the less stable are both the exchange rate and the money demand function".

The monetary approach to balance of payments has largely been criticized for emphasizing that BOPs is in effect a monetary phenomenon (Howard \& Mamingi, 2002). Nevertheless, the fact that the monetary approach to balance of payments is said to be a monetary phenomenon does not mean that it claims all other factors are unimportant. Rather, the approach explains that, since disequilibria in the BOPs are caused by monetary imbalances, it would be more appropriate to use policy monetary policy tools to correct the disequilibrium. Opponents argued that the approach only declares that the consequence of increase in economic growth on BOPs should be examined with tools of monetary theory". 
In spite of the above disapproval, the approach is sensible because it considers external and domestic money. It emphasized the degree to satisfy the demand for genuine money balances from domestic sources, all the way through the creation of money or from external sources through excess or shortfall in the BOPs. Shortfall or excess in the BOPs can be corrected through adjustment in the supply of money and their resulting impacts on income and spending, or in general on the amount of goods produce and consume (Jhingan, 2012).

\section{Empirical Literature}

Because of the importance of this topic, a lot of research works have been carried out on it. For instance, Fleermuys (2005) empirically examined the monetary approach to the Namibian BOPs. The researcher collected secondary data from 1993 to 2003 and used econometrics method to analyze the data obtained. The regression results showed that monetary policy does not play an important role in determining Namibia's BOPs. The researcher discovered that, a number of variables recommended by monetary approach play important roles, but BOPs is not an entirely monetary occurrence.

Ditimi, Wosa \& Olaiya (2011) investigated the effect of monetary policy instrument on BOPs in Nigeria from 1986 to 2009. The researchers used ordinary least squares method of econometrics to analyze the secondary data obtained. The result showed that monetary policy has significant effect on BOPs and also it is a potent tool in maintaining BOPs that is favourable within Nigerian economy.

In Nigeria, as at 2012, Imoisi used OLS technique to look at trends in balance of payments for the duration of 1970 to 2010. The result showed that the independent variables such as exchange rate, inflation rate and interest rate appeared with the correct sign and thus, conforms to economic theory, but the there exists an insignificant association flanked by inflation rate and balance of payments. Meanwhile, there exists a significant association connecting exchange rate, interest rate and balance of payments.

In an attempt to understand the impact of monetary policy on the Nigerian economy, Onyeiwu (2012) collected time series data from 1981 to 2008 and used the Ordinary Least Squares Method of econometrics to analyze the data. The regression result showed that monetary policy variable of money supply impacts positively on BOPs during the period of study.

Furthermore, Boateng \& Ayentim (2013) systematically examined Balance of Payments in Ghana. The researcher made use of time series data from 1980 to 2010. The study employed monetary approach and econometric methods/models. The study showed that the balance of payments imbalance in Ghana is not controlled only by monetary policy. The results also showed that variables such as GDP growth, domestic credit, interest rate have a significant relationship with BOPs. Moreover, interest rate and Domestic credit are negatively linked to net foreign assets while GDP growth is positively related. In addition, Inflation is not significantly related to net foreign assets. The study therefore concluded that for monetary policy to correct the disequilibrium in BOPs, government should give equal attention to other macroeconomic policies.

Danjuma (2013) examined the role excess money supply has played in the position of balance of payments in Nigeria from 1986 to 2010. Johansen Cointergration, Vector Error Correction Mechanism and the Impulse Response Function and Variance Decomposition were the methods used in analyzing the annual data. The results of VECM and impulse responses confirmed that balance of payments in Nigeria is not a purely monetary phenomenon in line with similar studies in other countries.

Tijani (2013) empirically investigated BOPs Adjustment Mechanisms using Monetary Channel in Nigeria from 1970 to 2010. The study made use of time series data and econometric method of OLS to analyze the data obtained. The regression result showed that there is a positive relationship between the BOPs and Exchange Rate, Domestic Credit and Balance of Trade while Gross Domestic product and Inflation Rate have a negative effect on BOPs. The study summarized that monetary measures contribute immensely to the position of BOPs of Nigeria, depending on the way it is applied by the monetary authority. 
Similarly, Imoisi, Olatunji and Ekpenyong (2013) jointly examined the power of monetary policy in achieving stability in the BOPs of Nigeria. They made use of time series data from 1980 to 2010 and Ordinary Least Squares (OLS) technique as the main analytical tool. The result showed a positive association between BOPs and all the monetary policy variables such as; Interest Rate, Money Supply and Exchange Rate. In particular, the result showed that Interest Rate and Money Supply had significantly impacted on BOPs during the period of study, whereas Exchange Rate was not statistically significant. Therefore, the study recommended that the government should encourage the exportation of goods and services especially the Non oil products.

Moreover, Ajayi (2014) find out the determinants of BOPs in Nigeria from 1970 to 2010. To achieve the objective of the study, the study used data on money supply, BOPs and monetary policy rate (MPR). The Econometric method of co-integration was used as the analytical tool. The researcher found a negative significant association between variables monetary policy (i.e. money supply and monetary policy rate) and BOPs. The study concluded that a better exchange rate and a smaller monetary policy rate will raise the BOPs of the Nigerian economy.

Udude (2015) did well to examine empirically the impact of monetary policy on Nigerian BOPs. Time series data were collected on exchange rate (EXCR), Balance of Payments (BOPs), Interest rate (INT), gross domestic product (GDP) and broad money supply (M2), from 1980 to 2010. However, Ordinary Least Squares (OLS) and Co-integration techniques were used as the main analytical tools. The results showed that there is a long run association among the variables. Also, the coefficients of M2 and EXCR were positive while those of INT and GDP were negative. Furthermore, all the coefficients of variables except interest rate were statistically significant. Therefore, monetary policy instruments significantly impact on the BOPs.

Imoughele and Ismaila (2015) examined monetary policy and BOPs in Nigeria from 1986 to 2013. In order to achieve the objective, the study used time-series data and Error Correction Model (ECM) to analyze the data. The result revealed that there exist a Long run association between monetary policy variables (Exchange rate, Broad money supply and credit to the private sectors) and BOPs. That is, exchange rate, broad money supply and credit to the private sectors are the main variables that determine BOPs in Nigeria. The study therefore concluded that BOPs is a monetary occurrence hence; monetary policy is the appropriate tool that can be used by monetary authority to improve and stabilized Nigeria's foreign sector performance.

\section{Materials and Methods}

The data collected and utilized in this work were from CBN's Statistical Bulletin. It covers the period 1970-2015. The unit root test, Co-integration test and Error Correction mechanism were employed as the main analytical tools. Moreover, the study utilized an econometric model aimed at capturing the relationship between balance of payments and monetary policy variables (money supply, interest rate, exchange rate and credit to private sector) in Nigeria, in line with the conceptual, theoretical and empirical literature reviewed. Specifically, this work adapted the model of Imoisi, (2012) who also adapted the monetary approach to balance of payments. That is, the model was cast in agreement with that of Imoisi (2012), whose model is in the form BOP = f (EXR, INF, IR) but with slight modification. The model for this study is presented thus: BOP $=\mathrm{F}\left(\mathrm{M}_{2}, \mathrm{INR}, \mathrm{EXR}, \mathrm{CPS}\right)$

$\mathrm{BOP}_{\mathrm{t}}=\mathrm{a}_{\mathrm{o}}+\mathrm{a}_{1} \mathrm{M}_{2 \mathrm{t}}+\mathrm{a}_{2} \mathrm{INR}_{\mathrm{t}}+\mathrm{a}_{3} \mathrm{EXR}_{\mathrm{t}}+\mathrm{a}_{4} \mathrm{CPS}+\mathrm{u}_{\mathrm{t}}$

Where; $\mathrm{BOP}=$ Balance of Payments, $\mathrm{M}_{2}=$ Money Supply, INR = Interest Rate, EXR= Exchange Rate, CPS = Credit to Private Sector, $\mathrm{u}=$ Error Term, $\mathrm{a}_{0}=$ The constant parameter, $\mathrm{a}_{1}, \mathrm{a}_{2}, \mathrm{a}_{3}$ and $\mathrm{a}_{4}>0=$ The slope parameters

On the apriori: $a_{1}>0, a_{2}<0, a_{3}>0$ and $a_{4}>0$. Furthermore, unit root test encompasses testing the order of integration of the individual series in a model precedes Co-integration and ECM. The unit root test used in this study is the Augmented Dickey-Fuller (ADF). The general form of ADF is estimated by the following regression $\triangle$ RGDP ${ }_{\mathrm{t}}$ $=\alpha_{0}+\alpha_{1} \mathrm{BOP}_{\mathrm{t}-1}+\Sigma \alpha_{1} \Delta \mathrm{BOP}_{\mathrm{i}}+\delta_{\mathrm{t}}+\mathrm{u}_{\mathrm{t}}$ (3.3) Where: BOP is a time series, $t=$ time, $\Delta=$ first difference operator, $\alpha_{0}=$ constant, $\mathrm{n}=$ number of lags in the explanatory variables and $\mathrm{u}=$ random error term. The Johansen co- 
integration procedure was used in this study. According to Johansen (1998), the general form of co-integration is given by $\mathrm{BOP}_{\mathrm{t}}=\mu+\Delta_{1} \mathrm{BOP}_{\mathrm{t}-1}+\cdots+\Delta \mathrm{P} \mathrm{y}_{\mathrm{t}-\mathrm{p}}+\mathrm{u}_{\mathrm{t}}$

Where: $\mathrm{BOP}_{\mathrm{t}}$ is an $\mathrm{nx} 1$ vector of variables that are integrated of order commonly denoted (1) and $\mathrm{u}_{\mathrm{t}}$ is an $\mathrm{nx} 1$ vector of innovations. However, an extension of this in the co-integration technique is the Error Correction Mechanism (ECM) (Engle and Granger, 1987). These authors have established that Co-integration is a sufficient condition for an Error Correction Model formulation.

In addition, if co-integration is proven to exist, then the next step requires the construction of Error Correction Mechanism (ECM) to model dynamic relationship. The study represents the model specification with an error correction form that allows for inclusion of long-run information thus, the ECM can be formulated as follows: $\Delta \mathrm{BOP}_{\mathrm{t}}=\beta_{0}+\Sigma \beta_{1} \Delta \mathrm{BOP}_{\mathrm{t}-1}+\Sigma \beta_{2} \mathrm{M}_{2} \Delta_{\mathrm{t}-1}+\Sigma \beta_{3} \Delta \mathrm{INR}_{\mathrm{t}-1}+\Sigma \beta_{4} \Delta \mathrm{EXR}_{\mathrm{t}-1}+\Sigma \beta_{4} \Delta \mathrm{CPS}_{\mathrm{t}-1}+\delta_{1} \mathrm{ECM}_{\mathrm{t}-1}+\mu_{1-\mathrm{t}}$ (3.5). Note; the variables as earlier defined.

\section{Results and Discussion}

To avoid spurious regressions which may arise as a result of carrying out regressions on time series data, we first subjected the data to stationarity test by using the Augmented Dickey Fuller (ADF) tests. See Table 4.1 for detailed result of the ADF test.

Table 4.1: Unit Root Test (1970-2015)

\begin{tabular}{|l|l|l|l|l|l|}
\hline Variables & ADF Test & \multicolumn{2}{|l|}{ Critical Values } & \multicolumn{2}{c|}{$\begin{array}{c}\text { Order of } \\
\text { integration }\end{array}$} \\
\cline { 2 - 6 } & & critical value 1\% & critical value 5\% & Critical value 10\% & \\
\hline BOP & -7.740107 & -3.632900 & -2.948404 & -2.612874 & $1(2)$ \\
\hline EXR & -6.674919 & -3.588509 & -2.929734 & -2.603064 & $1(1)$ \\
\hline INR & -7.069027 & -3.592462 & -2.931404 & -2.603944 & $1(1)$ \\
\hline CPS & -9.377632 & -3.592462 & -2.931404 & -2.603944 & $1(2)$ \\
\hline M2 & -8.383035 & -3.596616 & -2.933158 & -2.604867 & $1(2)$ \\
\hline
\end{tabular}

Note: BOP, EXR, INR, M2 and CPS as earlier defined

Source: Authors' Computed Result from (E-views 8)

The stationarity test result presented in Table 4.1 shows that at various levels of significance (1\%, 5\% and 10\%), the variables were stationary. Although the variables were not stationary at level, in line with Granger and Newbold (1974), the variables were differenced. Thus, EXR and INR became stationary at first difference (integrated of order one).While the other variables such as BOP, CPS and $\mathrm{M}_{2}$ were integrated of order two. Hence, the series were subjected to co-integration test.

\section{Test for Co-integration}

Test for co-integration was conducted based on the test proposed by Johansen. According to Iyoha and Ekanem, (2002) co-integration deals with the methodology of modeling non-stationary time series variables. For detail result of the Johansen co-integration, see the table 4.2 below. 
Table 4.2: Johansen Test for Co-integration

\begin{tabular}{|c|c|c|c|c|}
\hline Eigen value & Trace Statistic & 5\% critical value & Prob. $* *$ & $\begin{array}{l}\text { Hypothesis of } \\
\text { CE(s) }\end{array}$ \\
\hline 0.994768 & 299.4596 & 69.81889 & 0.0001 & None $^{*}$ \\
\hline 0.661740 & 78.83202 & 47.85613 & 0.0000 & At most 1 $^{*}$ \\
\hline 0.435128 & 33.30652 & 29.79707 & 0.0189 & At most 2 $^{*}$ \\
\hline 0.197664 & 9.317975 & 15.49471 & 0.3368 & At most 3 \\
\hline 0.001627 & 0.068393 & 3.841466 & 0.7937 & At most 4 \\
\hline
\end{tabular}

Source: Computed Result Using (E-Views 8)

The Table 4.2 indicates that there are three co- integrating equations because three of the Trace Statistic(s) are larger than critical value at 5\%. Therefore, there is a long-run relationship among BOP, EXR, INR, CPS and M2. Given that there are three co-integrating equations, the requirement for fitting in an error correction model is satisfied.

\section{Table 4.3: Parsimonious Error Correction Model}

Dependent Variable: $\mathrm{D}(\mathrm{BOP})$

\begin{tabular}{crrrr}
\hline \hline Variable & Coefficient & Std. Error & t-Statistic & Prob. \\
\hline \hline C & 37165.23 & 114132.3 & 0.325633 & 0.7468 \\
D(BOP(-1)) & 0.343186 & 0.329864 & 1.040385 & 0.3057 \\
D(BOP(-2)) & 0.042118 & 0.248343 & 0.169595 & 0.8664 \\
D(BOP(-3)) & 0.287722 & 0.206375 & 1.394173 & 0.1726 \\
D(EXR(-1)) & 16047.34 & 7375.412 & 2.175789 & 0.0368 \\
D(M2(-1)) & -0.238512 & 0.150062 & -1.589424 & 0.1215 \\
D(INR(-1)) & -29017.46 & 32034.74 & -0.905812 & 0.3716 \\
D(CPS(-1)) & -0.150747 & 0.072638 & -2.075308 & 0.0458 \\
ECM(-1) & -1.043324 & 0.355043 & -2.938584 & 0.0060 \\
\hline \hline R-squared & 0.723033 & Mean dependent var & -128565.4 \\
Adjusted R-squared & 0.655890 & S.D. dependent var & 1009945. \\
S.E. of regression & 592442.9 & Akaike info criterion & 29.60931 \\
Sum squared resid & $1.16 E+13$ & Schwarz criterion & 29.98166 \\
Log likelihood & -612.7954 & Hannan-Quinn criter. & 29.74579 \\
F-statistic & 10.76848 & Durbin-Watson stat & 2.201885 \\
Prob(F-statistic) & 0.000000 & & \\
\hline \hline
\end{tabular}

Note: BOP, EXR, INR, M2 and CPS as earlier defined.

Source: Computed Result Using (E-Views 8)

Table 4.3 indicates that the dynamic model is a good fit. The reason is that the difference in our predictors account for 72 percent of the overall disparity in our model looking at the $\mathrm{R}^{2}$. Put differently, the $\mathrm{R}^{2}$ value of 0.72 indicates that the variation in balance of payments explained by exchange rate, interest rate, money supply and credit to private sector is 72 percent. Therefore, the explanatory power of the model estimated is 72 percent. The Durbin Watson (DW) value of 2.2 which is approximately 2.0 , suggests that the model is free from autocorrelation.

Moreover, an important characteristic to be noticed in Table 4.3 is the coefficient of the parameter of error correction term. The coefficient of the error correction term appears with the right sign (i.e., negative) and 
statistically significant. It therefore, follows that the ECM could rightly correct any deviations from short run to long-run equilibrium relationship between balance of payments and the explanatory variables.

However, the coefficient of exchange rate (EXR) has the right sign (i.e., positive), this implies a positive relationship between exchange rate and balance of payments. This conforms to apriori expectation. This means that a strong value of the naira in relation to dollar will raise the balance of payments of the country. Moreover, the absolute value of the t-statistic for the slope coefficient is significant at conventional level (i.e., $5 \%$ ). This also means that exchange rate significantly impacted on balance of payments during the period of study. Put differently, the implication of this result is that exchange rate variable has the ability to raise the balance of payments position of Nigeria. Hence, if exchange rate policy is managed very well it will stabilize the balance of payments of Nigeria. The significant relationship between exchange rate and balance of payments reflect the potency of the variable (i.e., exchange rate) as an important conduct in transmitting monetary policy impulses to the aggregate economy thereby raising the balance of payments position. This is consistent with earlier studies including Tijani (2013) who reported the existence of a significant relationship between exchange rate and balance of payments in Nigeria.

In addition, the coefficient of money supply (M2) appears with the wrong sign (i.e., negative) instead of positive; implying a negative relationship between money supply and balance of payments. However, the absolute value of the t-statistic for the slope coefficient of money supply is not significant at conventional level (i.e., $5 \%$ ). The implication of this result is that money supply has not significantly impacted on balance of payments during the period of study. It also implies that money supply alone as a monetary policy tool will not significantly lead to a rise in balance of payments in Nigeria. This also means that monetary policy towards money supply has not been well articulated and coordinated towards raising balance of payments situation of the country from 1970 to 2015 based on the model. This may be as a result of the inability of the monetary authorities to keep the money supply growing at an appropriate rate so as to secure a sustainable economic growth and maintain external balance. This is consistent with earlier studies including Onyeiwu (2012) and Imoisi, et al (2013) who reported non existence of a significant relationship between money supply and balance of payments in Nigeria.

At the same time, the coefficient of credit to private sector (CPS) appears with the wrong sign (i.e., negative) instead of positive. But this does not conform to the apriori expectation. Meanwhile, credit to private sector (CPS) is statistically significant at conventional level (i.e., 5\%). This also means that monetary policy towards credit to private sector has been well articulated and coordinated towards raising balance of payments situation of the country from 1970 to 2015 . The significant relationship between credit to private sector and balance of payments reflect the potency of the variable (i.e., credit to private sector) as an important conduct in transmitting monetary policy impulses to the aggregate economy thereby raising the balance of payments position.

Furthermore, the coefficient of interest rate (INR) appears with the right sign (i.e., negative). This reveals the existence of a negative relationship between interest rate and balance of payments in Nigeria. However, the absolute value of the t-statistic for the slope coefficient of interest rate is not significant at conventional level (i.e., 5 $\%)$. This means that there is no significant relationship between interest rate and balance of payments. The implication of this result is that interest rate variable has not significantly impacted on balance of payments position of Nigeria during the period of study. This finding is consistent with earlier studies including Udude (2015) who reported non existence of a significant relationship between interest rate and balance of payments in Nigeria.

Nevertheless, it is clear from the above result that only credits to private sector and exchange rate have significantly impacted on balance of payments in Nigeria during the period of study while other variables (money supply and interest rate) do not. That is, explanatory variables such as interest rate and money supply are statistically insignificant while credits to private sector and exchange rate are statistically significant.

The insignificant relationship effect of interest rate and money supply, suggest that monetary policy regarding interest rate and money supply had been inactive in influencing or raising the balance of payments situation. This could step from the dominance of fiscal measures especially government expenditures in achieving 
macroeconomic objectives in Nigeria. This could also be attributed to high interest rates which are excessively high, to the extent that investors are discouraged from securing credit from the banking sector.

\section{Conclusion and Recommendations}

This study on the impact of monetary policy on balance of payments in Nigeria from 1970-2015 is very important because it examined empirically the degree to which Nigeria's monetary policy influenced balance of payments in Nigeria from 1970 to 2015. With the utilization of data on balance of payments (BOPs), interest rate (INT), money supply (M2), exchange rate (EXR) and credit to private sector (CPS) from CBN Statistical Bulletin and the used of Co-Integration and Error Correction methods of econometrics to analyze the data so as to know the relationship that exist among the variables. The regression result reveals that exchange rate and credit to private sector have significant impact on balance of payments in Nigeria. While money supply and interest rate do not have significant impact on balance of payments in Nigeria. The study concluded that monetary policy plays an important role in determining Nigeria's BOPs. Therefore, the study recommended that monetary authority should adopt a managed floating exchange rate policy to redress the problem of exchange rate variation in order to raise the BOPs position of Nigeria and make the financial sector to be viable in order to provide credit at lower interest rates. There should be a well combination and coordination of both monetary and fiscal policies to achieve a favourable balance of payments and hence economic development in Nigeria. That is, for monetary policy to be effective in ensuring favourable balance of payments, it should be complemented with an effective fiscal policy. Moreover, commercial banks should increase their credit to private sector and government should focus on creating an enabling environment which will stimulate private sector investments. To achieve this, government should provide conducive infrastructure, build human capital (education, health care and technological know-how); govern effectively in the public interest; and orient the economy towards diversified, export-oriented development based on national comparative advantage.

\section{REFERENCES}

[1] Adamu, P. \& Itsede, O. (2010) "Balance of Payments Adjustment: The West African Monetary Zone Experience". Journal of Monetary and Economic Integration, Vol 10 No2.

[2] Ajayi F. O. (2014). Determinants of Balance of Payments in Nigeria: A Partial Adjustment Analysis Journal of African Macroeconomic Review Vol. 5, No. 1 (2014).

[3] Akpakpan, B. E. (1994). How to Save the Naira and Nigeria: (Macroeconomics in Action) Belpot (NIG.) CO. (Publishing Division) No. 51 Ikot Ekpene Road, Abak Akwa Ibom State, Nigeria.

[4] Akpakpan, B. E. (1999). The Economy Towards a New Type of Economics. Port Harcourt: New Generation Publishers.

[5] Alawode, A. A. (1997). Some Criticisms of the Monetary Approach to the Balance of Payments.

[6] Anyanwu, J. C. \& Oaikhenan, H. E. (1995). Modern Macroeconomics: Theory and Application in Nigeria. Onisha: Joanuee Publishers.

[7] Boateng, C. \& Ayentim D. T. (2013) An Experimental Analysis of BOP in Ghana. Journal of European Business and Management. Vol.5, No.8, 2013

[8] Bobai, (2013), An Empirical Analysis of the Balance of Payments as a Monetary Phenomenon: Nigeria's Experience: Journal of Emerging Issues in Economics, Finance and Banking (JEIEFB) An Online International Monthly Journal (ISSN: 2306 367X) Volume: 1 No.2 February 2013

[9] Central Bank of Nigeria (CBN) Annual Economic Report (2013, Pg. 161).

[10] Central Bank of Nigeria (CBN) Annual Economic Report (2014, Pg. 163).

[11] Central Bank of Nigeria (CBN) Annual Economic Report (2015, Pg. 199).

[12] Danjuma, B. F (2013). An Experimental Analysis of the BOP as a Monetary Occurrence: Nigeria's Experience. Journal of Emerging Issues in Finance, Banking and Economics 1(2), ISSN: 2306 367X 
International Journal of Science and Management Studies (IJSMS)

Volume: 02 Issue: 03
May to June 2019
E-ISSN: 2581-5946

www.ijsmsjournal.org

[13] Dhliwayo, R. (1996). The Balance of Payments as a Monetary Phenomenon: An Econometric Study of Zimbabwe's Experience. African Economic Research Consortium (AERC), Research Paper 46. Nairobi

[14] Ditimi, A., Nwosa P.I \& Olaiya, S.A (2011): An Assessment of Monetary Policy and its Effect in Stabilizing Macro Economic Variables in Nigeria. Emerging Trends in Management Sciences and Economics Journal (JETEMS), 2 (3): 232-237

[15] Fleermuys, F. (2005). “The BOP as a Monetary Occurrence: An Econometric Study of Namibia”. DEA Research Discussion Paper No.72.

[16] Gbosi, A. (2001). Modern Macroeconomic Troubles and Stabilization Policies. Port Harcourt: Antoric Ventures.

[17] Gbosi, A. N. (2011). External Trade in Theory and Practice. Port Harcourt: Amethyst \& Colleagues Publishers.

[18] Gbosi, A. N. (2015).Contemporary Macroeconomic Problems and Stabilization Policies. Port Harcourt: Antoric Ventures.

[19] Gbosi, A. N. (2005). Money, Monetary Policy and the Economy: Abigap Associates Ltd Confidence Estate 28 Itu Road Uyo, Akwa Ibom State.

[20] Granger, C. W. J. and P. Newbold, 1973, Some Comments on the Evaluation of Economic fore- casts, Applied Economics 5, 35-47.

[21] Howard, M. \& N. Mamingi. (2002). The Monetary Approach to the Balance of Payments: An application to Barbados. The Singapore Economic Review, 47(2):213-228.

[22] Imoisi, A. I. (2012).Trends in Nigeria's Balance of Payments: an Empirical Analysis from 1970-2010. European Journal of Business and Management Vol 4, No.21, 2012.

[23] Imoisi, A., Olatunji, L. \& Ekpenyong, B. (2013). Monetary Policy and Its Implications for BOP Stability in Nigeria. Journal of International Finance and Economics 5(3), ISSN 1916-971X

[24] Iyoha, M. A. \& Ekanem O.T. (2002). Introductory Econometrics. Benin City: Mareh Publishers.

[25] Imoughele, L. E. \& Ismaila, M. (2015). Monetary Policy and BOP Stability in Nigeria. International Journal of Academic Research in Public Policy and Governance Vol. 2, No. 1 ISSN 2312-4040 January 2015,

[26] Jhingan, M. L. (2012). Monetary Economics: Vrinda Publication (P) LTD B-5 Ashish Complex (opp. Ahlcon Public School), Mayur Vihar, Phase-1, Delhi-110 091.

[27] Lanciaux, B. (1990). An Institutional Analysis of the Monetary Approach to the Balance of Payments. Journal of economic issues, 24(2):433-441.

[28] Onyeiwu, C. (2012). Monetary Policy versus Economic Growth of Nigeria: Economics and Sustainable Development Journal, 3 (7), $62-71$.

[29] Robinson, M. O. (2003). International Economics. Port Harcourt: Harey Publications Company.

[30] Tijani, J. O. (2013). An Experimental Scrutiny of BOP Adjustment Mechanisms: 'M' Channel in Nigeria, 1970-2010, Mediterranean Journal of Social Sciences, 5(14):67-76.

[31] Udude, C. C. (2015). Monetary Policy and BOP in Nigeria (1981-2012). Journal of Policy \& Development Studies No. 2, Vol. 9 , ISSN: 157-9385, February 2015.

[32] Umer, M., Muhammad, S. D., Abro, A. A., Sheikh, Q. A., and Ghazali, A. (2010): The Balance of Payments as a Monetary Phenomenon: Econometric Evidence from Pakistan(http://www.eurojournals.com/finance.htm).

[33] Umo, J. U. (2012). Economics An African Perspective: Millennium Text Publishers Limited. Plot 6B, Block 22, Humanities Road Unilag Estate, Magodo, Isheri, Lagos, Nigeria.

[34] Unaikobo, I. B., \& Enoma, A. (2011). Exchange Rate Depreciation and Inflation in Nigeria (1986-2008). Economic and Business Volume 28(1) Journal, 2011. 